Japan. J. Med. Sci. Biol., 36, 199-207, 1983

\title{
IDENTIFICATION OF GROUP A COXSACKIEVIRUSES BY IMMUNE ADHERENCE HEMAGGLUTINATION
}

\author{
Osamu NiShio, Junko SUMI, Yuichi ISHIHARA, Kenji SAKAE \\ and Hiromasa INOUE
}

Aichi Prefectural Institute of Public Health, Tsuji-machi, Kita-ku, Nagoya 462

(Received April 2, 1983. Accepted June 17, 1983)

\begin{abstract}
SUMMARY: We investigated to find whether the immune adherence hemagglutination (IAHA) test could be used for identification of group A coxsackieviruses (Cox. A). By using homogenate of suckling mouse torsos infected with each of nine prototype viruses (Cox. A 2, 3, 4, 5, 6, 8, 9, 10 and 16) and 46 isolates as antigens and hyperimmune mouse ascitic fluids to the prototype viruses, we compared IAHA with complement fixation (CF) for serotyping of these viruses. The results of identification tests by IAHA were the same as those by combined use of CF and neutralization tests on all the 46 strains. By CF alone, however, six of 46 strains were not identified because of lower antigen titers; IAHA antigen titers were generally higher by 16-fold or more than CF tests. Furthermore, IAHA had a higher typespecificity than CF; a weak cross-reaction was found by IAHA only between Cox. A 3 and Cox. A 8. Nonspecific reactions encountered in IAHA were reduced more readily by kaolin than fluorocarbon treatment of the torso homogenates. From these results, we conclude that IAHA is an alternative method to CF and neutralization for serotyping of Cox. A viruses.
\end{abstract}

\section{INTRODUCTION}

Coxsackieviruses (Cox.) are classified into two groups (A and B) according to their growth characteristics in mice. All six serotypes of Cox. B grow well also in cultured cells of human and monkey kidney origin. Many serotypes of Cox. A, however, grow so poorly in cell cultures that they have to be cultivated in infant mice (Behabehani, 1967). Therefore, the procedures to isolate Cox. A viruses from clinical materials and to identify their serotypes are as follows: for virus isolation, clinical materials are inoculated to infant mice, which are observed for paralysis; for determination of serotypes, neutralization (NT) in mice is carried out, or complement fixation (CF) with use of the torso homogenate of infected mice as antigen is performed.

As an alternative technique to NT and CF, we investigated the feasibility of the immune adherence hemagglutination (IAHA) method for identification of Cox. A viruses; IAHA is known to be more sensitive than CF for detecting virus antigens (Ito and Tagaya, 1966; Mayumi et al., 1971; Inouye et al., 1980).

西尾 治・驚見順子・石原佑式 - 栄 賢司 - 井上裕正（愛知県衛生研究所 名古屋市北区辻町） 
This paper describes our findings showing that IAHA is an appropriate technique for that purpose.

\section{Materials ANd Methods}

Viruses: Prototype strains of Cox. A 2, 3, 4, 5, 6, 8, 9, 10 and 16 were provided by Drs. T. Komatsu and A. Hagiwara (Department of Enteroviruses, National Institute of Health, Tokyo). We used also 46 strains isolated in our laboratory in suckling ICR mice from stool or throat-swab specimens obtained from children with various illnesses (Nishio et al., 1978).

The torsos of paralysed mice inoculated with each of the prototype strains of Cox. A viruses or with clinical materials were added to about 10 volumes of phosphate buffer saline (PBS), and then triturated in a homogenizer (Nihon Seiki, Co., Tokyo) for $30 \mathrm{sec}$. After clarification by centrifugation at 10,000 rpm for $20 \mathrm{~min}$, the supernatant was treated once with an equal volume of fluorocarbon (Daikin Industry Co., Osaka) and the aqueous phase was used as antigen for IAHA and CF. Some of the supernatants were treated once with an equal volume of $25 \%$ kaolin (Fisher Scientific Co., USA) in PBS.

Immune ascitic fluids: Hyperimmune ascitic fluids to prototype viruses were produced in adult mice. The torso homogenates were treated twice with fluorocarbon, and then mixed with polyethyleneglycol 6000 to a final concentration of $8 \%$ to concentrate virus antigens (Yamamoto et al., 1970). The resultant precipitates were each resuspended in 0.05 volumes of saline for use as immunogens. The concentrated virus suspension was mixed with an equal volumes of Freund's complete adjuvant, and one-ml volumes were inoculated subcutaneously. Four weeks later, 1.0-ml of the immunogen without adjuvant was given into the intraperitoneal cavity as a booster injection. Additional boosters were given once or twice at one-week intervals. Then Ehrlich's ascite tumor cells were intraperitoneally inoculated $\left(10^{6}\right.$ cells $/$ mouse). Ascites harvested were used as a source of antibody.

$I A H A$ and $C F$ : The methods described by Inouye et al. (1981) were employed. Briefly, the IAHA test was carried out in the following way. Veronalbuffered saline containing $0.1 \%$ bovine serum albumin, $0.002 \%$ gelatin and $0.02 \% \mathrm{NaN}_{3}$ was used as a diluent throughout the test. Antigens and antibodies, in 25 - $\mu$ l volumes each, were mixed and inoculated in wells of U-bottom polystyrene microplates at room temperature for $1 \mathrm{hr}$. Then, $25-\mu \mathrm{l}$ of fresh guinea pig serum diluted 1:100 was added. The plates were covered and incubated at $37 \mathrm{C}$ for $40 \mathrm{~min}$. Then, $25-\mu \mathrm{l}$ of dithiothreitol $(3 \mathrm{mg} / \mathrm{ml})$ and $50-\mu \mathrm{l}$ of $0.4 \%$ human erythrocytes were added. Hemagglutination pattern was read $2 \mathrm{hr}$ or more after room temperature incubation of the plates.

The CF test was carried out in microplates with $5 \mathrm{CH} 50$ units of complement. 


\section{Results}

\section{Comparison between IAHA and CF in Homologous Reactions}

Checkerboard titrations by IAHA and CF were carried out with homologous antigens and antibodies of nine prototype viruses. The antigen titers are shown in Table I; IAHA antigen titers were 16- to 32-fold higher than CF antigen titers. The antibody titers at antigen concentrations of 4-units are shown in Table II; IAHA antibody titers were 4- to 16-fold higher than CF antibody titers.

\section{TABLE I}

Comparison between antigen titers by IAHA and CF

\begin{tabular}{|c|c|c|}
\hline \multirow{2}{*}{ Antigen } & \multicolumn{2}{|c|}{ Antigen titer by } \\
\hline & IAHA & GF \\
\hline Cox. A 2 & 128 & 8 \\
\hline Cox. A 3 & 512 & 32 \\
\hline Cox. A 4 & 64 & 2 \\
\hline Cox. A 5 & 1024 & 32 \\
\hline Cox. A 6 & 128 & 8 \\
\hline Cox. A 8 & 256 & 16 \\
\hline Cox. A 9 & 64 & 4 \\
\hline Cox. A 10 & 128 & 8 \\
\hline Cox. A 16 & 64 & 4 \\
\hline
\end{tabular}

\section{TABLE II}

Comparison between antibody titers by IAHA and CF

\begin{tabular}{|c|c|c|}
\hline \multirow{2}{*}{ Immune ascites } & \multicolumn{2}{|c|}{ Antibody titer by } \\
\hline & IAHA & $\mathbf{C F}$ \\
\hline Anti-Cox. A 2 & 2560 & 320 \\
\hline Anti-Cox. A 3 & 640 & 80 \\
\hline Anti-Cox. A 4 & 640 & 40 \\
\hline Anti-Cox. A 5 & 2560 & 640 \\
\hline Anti-Cox. A 6 & 640 & 160 \\
\hline Anti-Cox. A 8 & 640 & 160 \\
\hline Anti-Cox. A 9 & 1280 & 320 \\
\hline Anti-Cox. A 10 & 1280 & 160 \\
\hline Anti-Cox: A 16 & 640 & 160 \\
\hline
\end{tabular}


TABLE III

IAHA antibody titration with homologous and heterologous antigens

\begin{tabular}{cc|cccccc}
\hline \multirow{2}{*}{ Ascites } & \multicolumn{5}{|c}{ IAHA antibody titer against } \\
\cline { 2 - 7 } & Cox. A 2 & Cox. A 3 & Cox. A 4 & Cox. A 5 & Cox. A 6 & Cox. A 8 \\
\hline Anti-Cox. A & 2 & $\underline{2560}$ & $<20$ & $<20$ & $<20$ & $<20$ & $<20$ \\
Anti-Cox. A & 3 & $<40$ & $\underline{640}$ & $<40$ & $<40$ & $<40$ & $<40$ \\
Anti-Cox. A 4 & $<40$ & $<40$ & $\underline{640}$ & $<40$ & $<40$ & $<40$ \\
Anti-Cox. A & 5 & $<20$ & $<20$ & $<20$ & 2560 & $<20$ & $<20$ \\
Anti-Cox. A & 6 & $<40$ & $<40$ & $<40$ & $<40$ & 640 & $<40$ \\
Anti-Cox. A & 8 & $<10$ & 40 & $<10$ & $<10$ & $<10$ & 640 \\
Anti-Cox. A 9 & $<20$ & $<20$ & $<20$ & $<20$ & $<20$ & $<20$ \\
Anti-Cox. A 10 & $<40$ & $<40$ & $<40$ & $<40$ & $<40$ & $<40$ \\
Anti-Cox. A 16 & $<40$ & $<40$ & $<40$ & $<40$ & $<40$ & $<40$ \\
\hline
\end{tabular}

\section{IAHA Antibody Titrations with Heterologous Antigens}

IAHA antibody titers of prototype immune ascites were determined with use of 4-unit antigens of homologous and heterologous types. Table III shows that all the ascites were highly type-specific. Only anti-Cox. A 8 ascite gave a slight cross-reaction with Cox. A 3 antigens.

Next, we studied further on this cross-reaction using three ascites preparations each of anti-Cox. A 3 and anti-Cox. A 8. Table IV shows that, by IAHA, all the anti-Cox. A 3 ascites did not cross-react with Cox. A 8 antigen, while two out of three anti-Cox. A 8 ascites reacted with Cox. A 3 antigen, indicating a one-way cross-reaction. By CF, the anti-Cox. A 8 ascites were more crossreactive with Cox. A 3 antigen; the difference between antibody titers against Cox. A 3 and Cox. A 8 was smaller by CF than by IAHA. This indicates that,

TABLE IV

Cross-reaction between Cox. A 3 and Cox. A 8

\begin{tabular}{c|c|c|cc|rr}
\hline & \multirow{2}{*}{ Ascites } & Lot No. & $\begin{array}{c}\text { Number of } \\
\text { booster } \\
\text { injections }\end{array}$ & \multicolumn{3}{|c}{ Antibody titer against } \\
\cline { 3 - 7 } & & & box. A 3 & Cox. A 8 & Cox. A 3 & Cox. A 8 \\
\hline & 1 & 1 & 320 & $<10$ & 40 & $<5$ \\
Anti-Cox. A 3 & 4 & 2 & 80 & $<10$ & 20 & $<5$ \\
& 7 & 3 & 640 & $<40$ & 80 & 5 \\
\hline & 6 & 3 & 40 & 640 & 20 & 80 \\
Anti-Cox. A 8 & 12 & 3 & 80 & 1280 & 20 & 160 \\
& 14 & 3 & $<10$ & 640 & 5 & 80 \\
\hline
\end{tabular}




\begin{tabular}{ccc}
\hline Cox. A 9 & Cox. A 10 & Cox. A 16 \\
\hline$<20$ & $<20$ & $<20$ \\
$<40$ & $<40$ & $<40$ \\
$<40$ & $<40$ & $<40$ \\
$<20$ & $<20$ & $<20$ \\
$<40$ & $<40$ & $<40$ \\
$<10$ & $<10$ & $<10$ \\
1280 & $<20$ & $<20$ \\
$<40$ & $\underline{1280}$ & $<40$ \\
$<40$ & $<40$ & 640 \\
\hline
\end{tabular}

in addition to its higher sensitivity, IAHA has higher type-specific reactivity than CF.

Identification of Cox. A Isolates by IAHA and CF

We previously isolated 46 Cox. A strains, which were identified by CF and NT (Cox. A 2, 5 strains; A 3, 3 strains; A 4, 8 strains; A 5, 8 strains; A 6, 6 strains; A 8, 3 strains; A 10, 7 strains; A 16, 6 strains) (Nishio et al., 1978). All these strains were again serotyped by IAHA and CF.

The results by IAHA on all 46 strains were the same as those by combined use of CF and NT. However, by CF alone, six of the 46 strains were not identified because of their low CF antigen titers. Table $\mathrm{V}$ shows the results on representative 14 strains.

In the IAHA tests, 34 of 46 torso specimens gave low-titered nonspecific hemagglutination in the antigen control wells containing no antibody (hemagglutination titer 1:2, 21 specimens; $1: 4,10$ specimens; 1:8, 1 specimen; 1:16, 2 specimens). We found that this nonspecific hemagglutination tended to be observed in the torso homogenates made from older suckling mice (over oneweek-old).

\section{Comparison of Kaolin to Fluorocarbon Treatments for Removal of Nonspecific Hemagglutination}

We used to pretreat the torso homogenates with fluorocarbon for IAHA and $\mathrm{CF}$ testing. As an alternative to fluorocarbon treatment, we tested kaolin treatment for removal of nonspecific hemagglutination.

Table VI shows that the nonspecific reactions were more readily removed by treatment with kaolin than with fluorocarbon. Also, specific IAHA antigen 


\section{TABLE V}

Identification of Cox. $A$ isolates by IAHA and CF

\begin{tabular}{|c|c|c|c|c|c|c|c|c|c|}
\hline \multirow{2}{*}{ Strains } & \multirow{2}{*}{$\begin{array}{l}\text { Number of } \\
\text { passages } \\
\text { in mice }\end{array}$} & \multicolumn{8}{|c|}{$\begin{array}{l}\text { IAHA antigen titers determined with } \\
\text { immune ascites to }\end{array}$} \\
\hline & & Cox. A2 & A3 & A4 & A5 & A6 & A8 & Al0 & A16 \\
\hline $1444 / 80$ & 1 & 512 & $<4$ & $<4$ & $<4$ & $<4$ & $<4$ & $<4$ & $<4$ \\
\hline $1146 / 79$ & 2 & 1024 & $<8$ & $<8$ & $<8$ & $<8$ & $<8$ & $<8$ & $<8$ \\
\hline $1202 / 80$ & 2 & $<4$ & 16 & $<4$ & $<4$ & $<4$ & $<4$ & $<4$ & $<4$ \\
\hline $1107 / 79$ & 1 & $<2$ & $<2$ & 128 & $<2$ & $<2$ & $<2$ & $<2$ & $<2$ \\
\hline $1123 / 80$ & 2 & $<8$ & $<8$ & 128 & $<8$ & $<8$ & $<8$ & $<8$ & $<8$ \\
\hline $1052 / 79$ & 1 & $<1$ & $<1$ & $\overline{<1}$ & $\underline{32}$ & $<1$ & $<1$ & $<1$ & $<1$ \\
\hline $1052 / 79$ & 3 & $<32$ & $<32$ & $<32$ & $\overline{256}$ & $<32$ & $<32$ & $<32$ & $<32$ \\
\hline $1430 / 80$ & 2 & $<8$ & $<8$ & $<8$ & $\overline{<8}$ & 64 & $<8$ & $<8$ & $<8$ \\
\hline $1141 / 78$ & 2 & $<32$ & $<32$ & $<32$ & $<32$ & $\overline{256}$ & $<32$ & $<32$ & $<32$ \\
\hline $1591 / 79$ & 1 & $<2$ & $<2$ & $<2$ & $<2$ & $\overline{<2}$ & 128 & $<2$ & $<2$ \\
\hline $1418 / 81$ & 1 & $<2$ & $<2$ & $<2$ & $<2$ & $<2$ & $\overline{<2}$ & 64 & $<2$ \\
\hline $1076 / 81$ & 1 & $<8$ & $<8$ & $<8$ & $<8$ & $<8$ & $<8$ & 512 & $<8$ \\
\hline $1592 / 79$ & 1 & $<1$ & $<1$ & $<1$ & $<1$ & $<1$ & $<1$ & $\overline{<1}$ & $\underline{32}$ \\
\hline $1353 / 80$ & 2 & $<1$ & $<1$ & $<1$ & $<1$ & $<1$ & $<1$ & $<1$ & $\overline{128}$ \\
\hline
\end{tabular}

$*$ Equivocal results

\section{TABLE VI}

Removal of nonspecific reactions by treatment with fluorocarbon or kaolin

\begin{tabular}{|c|c|c|c|c|c|c|}
\hline \multirow{4}{*}{ Strains } & \multirow{4}{*}{$\begin{array}{l}\text { Number of } \\
\text { passages } \\
\text { in mice }\end{array}$} & \multirow{4}{*}{ Identification } & \multicolumn{4}{|c|}{ Treatment with } \\
\hline & & & \multicolumn{2}{|c|}{ Fluorocarbon } & \multicolumn{2}{|c|}{ Kaolin } \\
\hline & & & \multicolumn{2}{|c|}{ Titers } & \multicolumn{2}{|c|}{ Titers } \\
\hline & & & Specific* & Nonspecific** & Specific & Nonspecific \\
\hline $2321 / 78$ & 1 & Cox. A 6 & 16 & $<1$ & 16 & $<1$ \\
\hline $1052 / 79$ & 1 & Cox. A 5 & 32 & $<1$ & 16 & $<1$ \\
\hline $1051 / 79$ & 2 & Cox. A 5 & 128 & 2 & 128 & 1 \\
\hline $1051 / 79$ & 3 & Cox. A 5 & 1024 & 2 & 512 & 2 \\
\hline $1091 / 80$ & 2 & Cox. A 4 & 128 & 4 & 16 & 1 \\
\hline $1082 / 80$ & 2 & Cox. A 4 & 128 & 4 & 32 & 1 \\
\hline $1077 / 81$ & 1 & Cox. A 10 & 256 & 4 & 256 & 1 \\
\hline $1076 / 81$ & 1 & Cox. A 10 & 512 & 4 & 256 & 1 \\
\hline $1570 / 78$ & 1 & Cox. A 10 & 128 & 8 & 128 & $<1$ \\
\hline $1052 / 79$ & 3 & Cox. A 5 & 256 & 16 & 128 & 2 \\
\hline
\end{tabular}

*: Specific hemagglutination titers with antibody in the IAHA test.

**: Nonspecific hemagglutination titers without antibody. 


\begin{tabular}{|c|c|c|c|c|c|c|c|c|c|c|}
\hline \multicolumn{8}{|c|}{$\begin{array}{l}\text { CF antigen titers determined with } \\
\text { immune ascites to }\end{array}$} & \multicolumn{3}{|c|}{ Identification by } \\
\hline Cox. A2 & A3 & A4 & A5 & A6 & A8 & Al0 & Al6 & IAHA & & CF \\
\hline 8 & $<1$ & $<1$ & $<1$ & $<1$ & $<1$ & $<1$ & $<1$ & Cox. A & 2 Cox. & A 2 \\
\hline$\underline{32}$ & $<1$ & $<1$ & $<1$ & $<1$ & $<1$ & $<1$ & $<1$ & A & 2 & A 2 \\
\hline$<1$ & 4 & $<1$ & $<1$ & $<1$ & $<1$ & $<1$ & $<1$ & A & 3 & A 3 \\
\hline$<1$ & $<\overline{1}$ & 8 & $<1$ & $<1$ & $<1$ & $<1$ & $<1$ & A & 4 & A 4 \\
\hline$<1$ & $<1$ & 16 & $<1$ & $<1$ & $<1$ & $<1$ & $<1$ & A & 4 & A 4 \\
\hline$<1$ & $<1$ & $<1$ & 2 & $<1$ & $<1$ & $<1$ & $<1$ & A & & $-*$ \\
\hline$<1$ & $<1$ & $<1$ & 16 & $<1$ & $<1$ & $<1$ & $<1$ & A & & A 5 \\
\hline$<1$ & $<1$ & $<1$ & $<1$ & $<1$ & $<1$ & $<1$ & $<1$ & A & 6 & - \\
\hline$<1$ & $<1$ & $<1$ & $<1$ & 8 & $<1$ & $<1$ & $<1$ & A & 6 & A 6 \\
\hline$<1$ & $<1$ & $<1$ & $<1$ & $<1$ & 4 & $<1$ & $<1$ & A & & A 8 \\
\hline$<1$ & $<1$ & $<1$ & $<1$ & $<1$ & $<1$ & 8 & $<1$ & A 1 & 10 & A 10 \\
\hline$<1$ & $<1$ & $<1$ & $<1$ & $<1$ & $<1$ & 16 & $<1$ & A 1 & 10 & A 10 \\
\hline$<1$ & $<1$ & $<1$ & $<1$ & $<1$ & $<1$ & $<1$ & 2 & A 1 & 16 & - \\
\hline$<1$ & $<1$ & $<1$ & $<1$ & $<1$ & $<1$ & $<1$ & 16 & A 1 & 16 & A 16 \\
\hline
\end{tabular}

titers were somewhat decreased. However, since IAHA antigen titers after kaolin treatment was still high and the specific hemagglutination pattern appeared more distinct after kaolin than fluorocarbon treatment, we now prefer the former to the latter treatment.

\section{Discussion}

Several investigators have used IAHA for the detection of virus antigens in serum (Mayumi et al., 1971), tissue culture fluids (Suzuki et al., 1979; Inouye et al., 1980; Suntharee et al., 1981) and stools (Matsuno et al., 1978; Nishio et al., 1981) because of its higher sensitivity than CF.

In this study, we also found that IAHA was 4- to 64-fold more sensitive than CF to detect Cox. A antigens in torso homogenates of infected suckling mice. Even if virus antigen could not be detected by CF because of low antigen titers, serotypes of isolates were easily identified by IAHA.

The cross-reaction observed in this study between Cox. A 8 and Cox. A 3 is in accordance with the results by CF and NT reported by other investigators (Kamitsuka et al., 1965; Munch, 1962; Suzuki et al., 1978). However, IAHA reaction was more type-specific than CF reaction (Table IV); this is in accordance with the report of Inouye et al. (1981). Yolken and Torsh (1981) observed cross-reactions between low-number and high-number Cox. A viruses 
by enzyme-linked immunosorbent assay. We are now intending to study on the cross-reactions by IAHA.

One problem of the IAHA technique lies in the fact that nonspecific hemagglutination was observed in $10 \%$ mouse torso suspension treated with fluorocarbon. This nonspecific activity was more readily removed by kaolin treatment. Although antigen titers were somewhat decreased by the kaolin treatment, this treatment can safely be used in identification by IAHA since IAHA is sensitive enough for the antigen detection.

The most important point in the IAHA test is the selection of human erythrocytes. When animal sera are used in the IAHA test, human erythrocytes of any blood type can be used. In this study, we always used erythrocytes from a healthy type $\mathrm{B}$ donor.

\section{ACKNOWLEDGEMENT}

We thank Dr. S. Inouye, Central Virus Diagnostic Laboratory, National Institute of Health, Tokyo, for his valuable advice and critical reading of the manuscript, and Drs. T. Komatsu and A. Hagiwara, Department of Enteroviruses, National Institute of Health, Tokyo, for providing Cox. A prototype viruses.

\section{REFERENCES}

Behabehani, A. M. (1967): Growth and cationic stabilization of group A coxsackievirus. Proc. Soc. Exptl. Med. Biol., 125, 983-988.

Inouye, S., Matsuno, S., Hasegawa, A., Mryamura, K., Kono, R. And Rosen, L. (1980): Serotyping of dengue viruses by an immune adherence hemagglutination test. Amer. J. Trop. Hyg., 29, 1389-1393.

Inouye, S., Matsuno, S. AND Kono, R. (1981): Difference in antibody reactivity between complement fixation and immune adherence hemagglutination tests with virus antigen. J. Clin. Microbiol., 14, 241-246.

Ito, M. AND TAGAYA, I. (1966): Immune adherence hemagglutination test as a new sensitive method for titration of animal virus antigens and antibodies. Japan. J. Med. Sci. Biol., 19, 109-126.

Kamitsuka, P., Lou, T. Y. And Wenner, H. A. (1965): Preparation and standardization of coxsackievirus reference antisera. 1. For twenty-four group A viruses. Amer. J. Epidemiol., $81,283-306$.

Matsuno, M. AND NAgAyoshi, S. (1978): Quantitative estimation of infantile gastroenteritis virus antigens in stools by immune adherence hemagglutination test. J. Clin. Microbiol., 7, 310-311.

MAyumi, M., Окосні, K. AND NishiokA, K. (1971): Detection of Australia antigen by means of immune adherence haemagglutination test. Vox. Sanguinis, 20, 178-181.

MuNch, B. S. (1962): On the specificity of complement fixation tests for typing of coxsackievirus strains. Acta Pathol. Microbiol. Scand., 56, 89-104.

Nishio, O., SAKAe, K., Kuno, A., Ishihara, Y. ANd Inoue, H. (1978): A continuing surveillance of enteroviruses in Aichi Prefecture. Clin. Virol., 6, 243-246 (in Japanese).

Nishio, O., Ishihara, Y., Sumi, J., Miyake, T., Sakae, K., Fujiura, A. And Inoue, H. (1981): Problem points and feasibility of rotavirus detection by IAHA test. Clin. Virol., 9, 64-68 (in Japanese).

Suzuki, T., Saito, N., Mochida, T., Kobayashi, I., Takamiya, A. and Kanayama, F. (1978): Cases of isolation of coxsackie A 3 virus. Japan. J. Publ. Hlth., 25, 288-290 (in Japanese).

Suzukr, T., Yoshida, Y., OdA, K. ANd TakamiYA, A. (1979): Application of immune adherence hemagglutination test for typing of enteroviruses. Virus, 20, 153-154 (in Japanese). 
Suntharee, R., Charnchudhi, C., Sompop, A., Kanai, C., Igarashi, A. And Inouye, S. (1981): Isolation and identification of dengue viruses by combined use of $\mathrm{C} 6 / 36$ cells and the immune adherence hemagglutination test. Japan. J. Med. Sci. Biol., 34, 375-379.

Yamamoto, K. R., Alberts, B. M., Benzinger, R., Lawhorne, L. And Treiber, G. (1970): Rapid bacteriophage sedimentation in the presence of polyethyleneglycol and its application to large scale virus purification. Virology, 40, 734-744.

Yolken, R. AND Torsch, V. (1981): Enzyme-linked immunosorbent assay for detection of coxsackieviruses A. Infect. Immun., 31, 742-750. 